\title{
Brain Storm
}





\section{Brain Storm}

The Flaws in the Science of

Sex Differences

REBECCA M. JORDAN-YOUNG

HARVARD UNIVERSITY PRESS

Cambridge, Massachusetts

London, England

2010 
Copyright (C) 20I0 by the President and Fellows of Harvard College All rights reserved

Printed in the United States of America

\section{Library of Congress Cataloging-in-Publication Data}

Jordan-Young, Rebecca M., I963-

Brain storm : the flaws in the science of sex differences / Rebecca M.

$$
\text { Jordan-Young. }
$$

$$
\text { p. } \mathrm{cm} \text {. }
$$

Includes bibliographical references and index.

ISBN 978-0-674-05730-2 (cloth : alk. paper)

I. Brain-Sex differences. I. Title.

QP8I.5.J67 20IO

6I2.8' 2 - de22 20I00IOI65 
For Sal 
